\title{
Removal of Organic Compounds Using Improved Wetland Systems for Wastewater Reuse As an Example of Local Sustainable Water Management
}

\author{
Wojciech Halicki (Corresponding author) \\ Department of Biology and Environmental Sciences \\ Cardinal Stefan Wyszynski University in Warsaw \\ Dewajtis 5, 00-001 Warsaw, Poland \\ E-mail: w.halicki@uksw.edu.pl
}

Katarzyna Kita

Department of Biology and Environmental Sciences

Cardinal Stefan Wyszynski University in Warsaw

Dewajtis 5, 00-001 Warsaw, Poland

Received: October 10, 2016 Accepted: November 11, 2016

doi:10.5296/emsd.v5i2.10357

URL: http://dx.doi.org/10.5296/emsd.v5i2.10357

\begin{abstract}
This paper discusses the efficiency of the removal of organic compounds using Improved Wetland System (IWS). IWS is used in Poland and enables reuse of treated effluent in landscape irrigation and toilet flushing. The first section of this paper discusses the advisability of removing organic compounds at the highest level. Additionally, the first section discusses the increase in frequency of treated wastewater reuse. So far, reuse of treated wastewater in local wastewater treatment systems included treatment and reuse of graywater only. The second section of this paper presents the average concentrations of organic compounds in domestic wastewater and the relationship existing between concentration of organic compounds in raw wastewater and water consumption. The second section discusses requirements for local (to 2000 population equivalent) wastewater treatment systems relating to reduction of organic compounds. The third section presents the current situation in rural areas in Poland and indicates the necessity of treated wastewater reuse mainly in these places. In Poland $43 \%$ of the overall population occupies rural areas and
\end{abstract}


about $70 \%$ of them are not connected to a wastewater network. Implementation of water reuse technology (mainly IWS) is the easiest and the cheapest in rural areas. The fourth section presents the principle and the construction of the Improved Wetland System with water reuse. This part shows defects of Constructed Wetlands hindering reuse of treated wastewater. Additionally, this section discusses different steps and efficiency of wastewater treatment. The fifth section discusses results of removing organic compounds depending on hydraulic and contaminant loads. In addition, this section presents guidance on designing the IWS with technology that enables water reuse for flushing toilets and landscape irrigation. The last part of this paper discusses the summary and economic aspects of IWS used in Poland. In addition, the last part shows existing IWS objects in Poland which provides water reuse to flushing toilets, landscape irrigation and for retention and recreational uses.

Keywords: Wastewater treatment, Wetland system, Organic compounds, Water reuse, Oxygen conditions, Anoxic conditions

\section{Introduction}

Reducing the use of natural resources is a key assumption of sustainable development. The need for water conservation and reuse is presently an important issue in the World. Despite this fact used water is infrequently reused. The reasons are lack of human awareness, high investment and operating costs. However, the major limiting factor is the lack of suitable technology which allows for the safe reuse of treated wastewater. General contaminants included in wastewater are divided into three groups: organic, biogenic, and sanitary (bacteria, viruses, fungi). From the viewpoint of reuse of treated wastewater the most important aspect is the removal of high levels of organic compounds. Low concentration of organic compounds in treated wastewater indicates a low number of sanitary contaminants such as bacteria, viruses and fungi (which consist of organic compounds). The sanitary contaminants may also be removed very easy by disinfection. From the viewpoint of reuse, biogenic compounds are less important than organic compounds because biogenic compounds are not a direct threat to humans. High reduction of organic compounds should be required, because organic compounds contain a large number of chemical natural and synthetic compounds. The synthetic compounds could be divided into:

- Pharmaceuticals - such as medicines and hormonal substances; in wastewater mainly from excreta

- Detergents - such as washing powders, whitening preparations, cleaning materials and degreasing agents, soaps, shampoos, hair conditioners, etc.

- "Chemicals at home" - such as wall paint, varnishes and solvents, which are used in household

- And others - such as petroleum substances, pesticides and cosmetic ingredients

Concentrations of the above-listed substances in domestic wastewater can be very low. Nevertheless, this compounds should be removed at the highest level to ensure safe reuse of treated wastewater. Therefore, the higher requirements are for organic compounds $\left(\mathrm{BOD}_{5}\right)$, suspended solids (TSS), total fecal coliform bacteria and nitrogen (Crook, 1998). So far, technology used in small local wastewater treatments plants cannot provide appropriate 
elimination of organic compounds which allows to reuse (Babock 2004). Therefore, development and implementation of Improved Wetland System achieves almost 100\% reduction in $\mathrm{BOD}_{5}$ and allows for safe reuse of treated wastewater in Poland. The necessity of water reuse appeared in the seventies during the $20^{\text {th }}$ century in the United States. Until the end of nineties water reuse was applied only in large wastewater treatment plants. After the years 2000 people began divert the water from small and local wastewater treatment plants. (Vassos, 2014). At the beginning the reuse of treated wastewater was implemented in water-poor areas but actually this technology is implemented everywhere. Currently, during implementation of water reuse both climatic and regional factors are taken into account (Nasiri, 2013). The key assumption of water reuse technology is to obtain a water which is safe for human health and life. Therefore, in local wastewater treatment plants mainly graywater is reused. Currently, there are many graywater treatment technologies (Allen, 2010). One way to treat graywater and reuse water was the use of Wetland Systems (Cho, 2007), (Jokerst, 2009). The Wetland Systems for wastewater treatment were used to a small extent for water reuse due to the low removal of organic compounds (reduction of $\mathrm{BOD}_{5}$ ) and sanitation compounds such as bacteria, fungi and protozoa. The low removal of organic and sanitation compounds in Wetland Systems were the main reason to create IWS, which guaranteed high organic and sanitation removal. In addition, treated wastewater is safe for human health and can be reused for flushing toilets and landscape irrigation.

\section{Concentrations of Organic Compounds in Wastewater and Required Concentrations of Pollutants in Outflow from Domestic and Local (Up To 2000 People Equivalent) Wastewater Treatment Plants in Poland}

To illustrate the amount of organic compounds that are present in wastewater we determined daily amount of contaminant load per capita such as: $60 \mathrm{~g} \mathrm{BOD}_{5}$ and $120 \mathrm{~g} \mathrm{COD} \mathrm{(Imhoff,}$ 1993). The amount of water consumption has an impact on the level of contaminant concentrations and contaminates loads in wastewater. Assuming that the average water consumption in Poland constitutes currently $100 \mathrm{dm}^{3} /$ day, the average concentration values of organic compounds is $600 \mathrm{~g} / \mathrm{m}^{3} \mathrm{BOD}_{5}$ and $1200 \mathrm{~g} / \mathrm{m}^{3}$ COD. The average concentration value in the case of wastewater flowing out of an individual building is independent of the number of people residing in the household. These values depend mainly on the amount of water used and the amount of time spent outside the home. The average concentration values of wastewater flowing from the septic tank are from $150-400 \mathrm{~g} / \mathrm{m}^{3} \mathrm{BOD}_{5}$ and from $300-800$ $\mathrm{g} / \mathrm{m}^{3}$ COD. Afterwards the wastewater is reduced to the required level depending on the location of the wastewater discharge. Table 1 shows required reduction of pollutants in domestic and local wastewater treatment plants in Poland.

Table 1. Required reduction of pollutants in domestic and local wastewater treatment plants in Poland (Halicki, 2015)

\begin{tabular}{|l|l|l|}
\hline Place of wastewater discharge & Values of organic compounds concentration in $\mathrm{g} / \mathrm{m}^{3}$ \\
\hline & $\mathrm{BOD}_{5}$ & $\mathrm{COD}$ \\
\hline To ditches and ponds & 25 & 125 \\
\hline To rivers and water streams & 40 & 150 \\
\hline
\end{tabular}




\section{Macrothink}

To provide the required reduction of the organic compounds in domestic and local wastewater treatment plants have to ensure at least $90 \%$ of the elimination in relation to the concentration of organic contaminants in wastewater flowing from the septic tank. The requirements shown in Table 1, do not enable the safe reuse of water because the level of organic compounds is not similar to the quality of clean water. In the clean waters BOD $_{5}$ value is below $2 \mathrm{mg} / \mathrm{dm}^{3}$ and COD is less than $20 \mathrm{mg} / \mathrm{dm}^{3}$ (Champon, 1996). In slightly polluted waters these values constitute maximum $6 \mathrm{mg} / \mathrm{dm}^{3}$ for $\mathrm{BOD}_{5}$ and $30 \mathrm{mg} / \mathrm{dm}^{3}$ for COD (Ministry of Environment, 2014) This high level of organic compounds reduction is practically not achievable using conventional wastewater treatment systems (based on trickling filter and activated sludge). In this situation, the wastewater should go through additional sand or membrane filters before reuse. However, this solution significantly increases the investment and operating costs and inhibits the reuse of treated wastewater.

\section{The Use of Water and Reuse of Treated Wastewater for Toilet Flushing and Landscape Irrigation in Poland}

In terms of water resources per capita, Poland is one of the most water-poor European countries $\left(1600 \mathrm{~m}^{3} / \mathrm{cap} / \mathrm{year}\right.$ ), and ranks as the $25^{\text {th }}$ country in Europe (Eurostat, 2015). Figure 1 shows the structure of water use for different sectors.

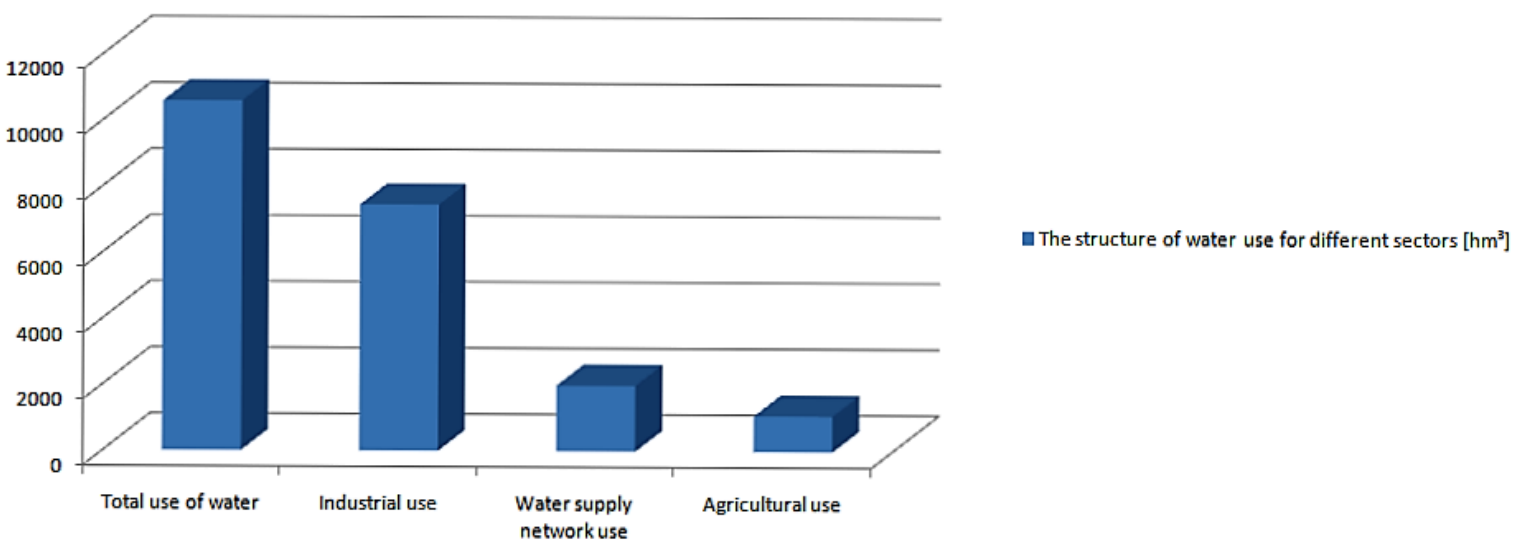

Figure 1. The structure of water use for industrial sectors, agricultural networks and water supply networks in Poland in 2014 (Eurostat, 2015)

Water supply network use in 2014 constituted approximately $19 \%$ of total water consumption in Poland. The analysis of the water use in a single household shows that one person consumes between 100 and 150 liters of water per day. Comparing Poland with the United States and other European countries this value is low, as shown in Figure 2. 


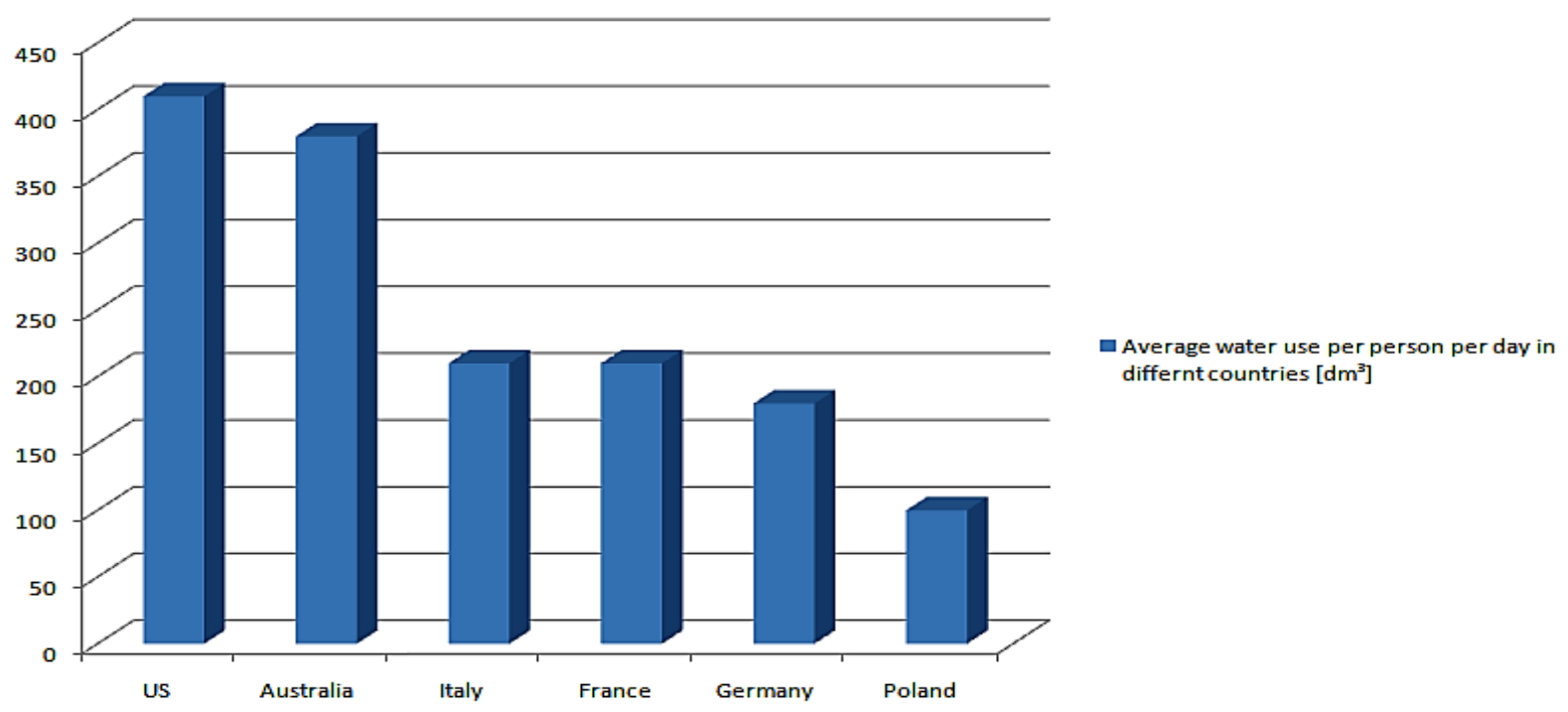

Figure 2. Average water use per person per day in different countries (Eurostat, 2014)

About $50 \%$ of water use in a household per one day is bath water and 30 to $40 \%$ is used for toilet flushing. In practice, the average water consumption in Poland in many areas is less than $100 \mathrm{dm}^{3}$ per one day. The average population density in Poland is about 123 people / $\mathrm{km}^{2}$. In this regard Poland occupies the $90^{\text {th }}$ place among countries with a relatively large share of rural population, which amounts to $43 \%$ in Poland (UNDP, 2006), (GUS, 2010). In rural areas there is the greatest demand for the construction of households and local wastewater treatment plants. In addition, in rural areas about $50 \%$ of the total use of water is for toilet flushing. Therefore, in rural areas reuse of water mainly for toilet flushing is appropriate. The villages which are not connected to water supply networks and wastewater networks, are the greatest challenges in achieving sustainable water and wastewater management. One of the possible ways to provide sustainable water and wastewater management in rural areas is the use of the Improved Wetland Systems (IWS), which can also be called "zero-discharge-technology". In recent years, this technology has been accepted in local communities and installed in 5600 households. It guarantees high level reduction of organic compounds and enables reuse of treated wastewater for toilet flushing and landscape irrigation.

\section{Improved Wetland System}

Conventional household treatment systems based on trickling filter or activated sludge have limited capacities for removing organic compounds to a level which allows reuse of water. In terms of treated wastewater quality, Constructed Wetlands - CWs (Free Water Surface CWs, CWs with Horizontal Subsurface Flow, and CWs with Vertical Subsurface Flow) are better than conventional household treatment systems. However, according to many years of experience by authors, CWs have the following disadvantages, which limit the reuse of treated water:

- FWS CWs effectively reduced all types of pollution, but only when the area of FWS CWs was approximately $15 \mathrm{~m}^{2}$ per person. The major disadvantage of this system is 
the increased land area required, compared to other CWs, and the decrease of effectiveness of treatment in winter.

- HF CWs. Approximately $5 \mathrm{~m}^{2}$ of bed area per person are required for correct operation. But with such surface area after several years of operation, plumbing problems often appeared and treatment efficiency significantly decreased. Only HF CWs with surfaces of approximately $10 \mathrm{~m}^{2}$ per person provided long-term elimination of contamination and enabled reuse of treated wastewater.

- VF CWs require approximately $2 \mathrm{~m}^{2}$ of bed area per person for proper operation. During the first years this system provided high levels of reduced organic compounds, coliform bacteria and phosphorus, and the total nitrification of ammonium nitrogen. The problem with VF CWS is a large amount of nitrates in the outflow. After several years of operation, treatment efficiency significantly decreased, due to clogging of the filtration bed. Increasing the area of the filtration bed to $5 \mathrm{~m}^{2}$ per person extends the effective operation for many years and causes the reduction of total nitrogen but only to $40 \%$.

IWS eliminates the disadvantages of Constructed Wetlands and enables the reuse of treated wastewater for toilet flushing and landscape irrigation. A diagram of IWS is shown in Figure 3. The IWS consists of the following parts: plant filter - occupies an area of $2 \mathrm{~m}^{2}$ per person and is operated at a hydraulic loading from 0.05 to $0.1 \mathrm{~m}^{3} / \mathrm{m}^{2} /$ per one day. $\mathrm{BOD}_{5}$ load makes up from 10 to $15 \mathrm{~g} / \mathrm{m}^{2} /$ day and COD load is from 20 to $30 \mathrm{~g} / \mathrm{m}^{2} /$ day. Filter depth is $80 \mathrm{~cm}$ and the surface is planted with one species of plants - Glyceria maxima. The plant filter consists of the following three parts: first layer - organic layer $(20-30 \mathrm{~cm})$ as shown in Figure 3. This layer consists of bark of trees and wood chips. The second part of the filter is made of a $30-40 \mathrm{~cm}$ thick layer of coarse sand. The second layer includes iron and calcium which improves the effect of the phosphorus elimination. The third part consists of $20 \mathrm{~cm}$ of gravel layer with drainage pipe to collect the clear water. Treatment pond occupies from 3 to $5 \mathrm{~m}^{2}$ per one person. Depth of water in the pond is on average $30 \mathrm{~cm}$. The retention time in the pond is from 20 to 30 days. The pond is planted with many species of plants like Calamus, Bulrushlake, Typha angustifolia and others. Part of the filter in the pond (variant A) consists of fine sand with a mixture of iron and lime.

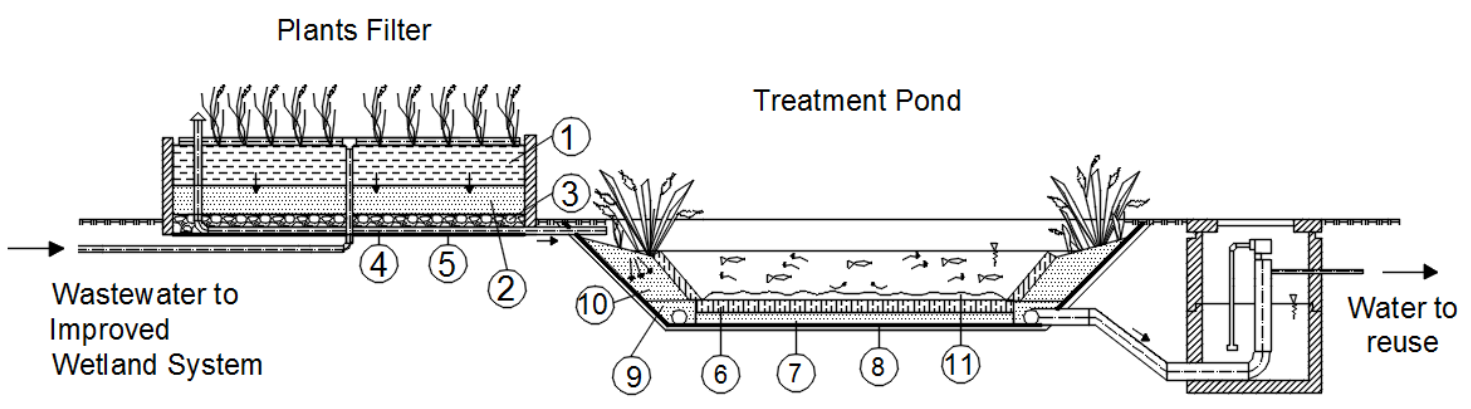

Figure 3. Diagram of the construction of an Improved Wetland System

1- organic layer, 2 - middle part of the filter, 3 - gravel layer, 4 - drainage pipe, 5 and 8 - 
impermeable liner, 7 - sand layer, 6 - concrete slab, 9 - gravel, 10 - filtration layer, 11 sediments

An example of a working IWS is shown in Figure 4. The total elimination of pollution was achieved by creating optimal conditions for individual treatment processes. In Constructed Wetlands, all treatment processes occur under the same conditions. Therefore, in IWS the treatment processes were divided into four stages in order to provide appropriate conditions for aerobic or anaerobic bacteria.

The first stage is pre-treatment in a septic tank which is common to all types of household wastewater treatment systems. This stage provides a maximal reduction of Biological Oxygen Demand $\left(\mathrm{BOD}_{5}\right)$ by $70 \%$ and COD to $60 \%$. The reduction of total suspended solids could be a maximal $90 \%$, and the reduction of nitrogen and phosphorus approximately $10 \%$.

The second stage is the biological treatment, which occurs in the upper organic layer (20 - 30 $\mathrm{cm}$ ) of the plant filter. The organic layer provides high levels of hydraulic conductivity and oxygen transfer rate and then acquires absorbent properties for organic pollutants in wastewater and maintains appropriate moisture. However, the most important advantages of the organic layer are the favorable conditions for the growth of heterotrophic bacteria and the development of micro and meso-fauna. These organisms transform organic compounds into $\mathrm{CO}_{2}, \mathrm{H}_{2} \mathrm{O}$, and plant nutrients. Thus, this system provides efficient elimination of organic substances (about 90\%) for many years.

The third stage is the removal of biogenic compounds in the middle part of the plant filter and in the treatment pond. The middle part of the plant filter is made of a $40 \mathrm{~cm}$ thick layer of coarse sand, in which autotrophic bacteria have favorable conditions for growth and for conducting the nitrification process. Wastewater in this layer is extremely limited due to the low content of organic compounds but contains a large amount of ammonium nitrogen, which is the main source of energy for nitrifying bacteria. The reduction of ammonium nitrogen in wastewaters after the third stage is about $90 \%$. In addition, calcium, aluminum, and iron-containing compounds are added to this layer, and as a result promote the chemical binding of phosphorus compounds within the layer. The fourth stage is water renewal, which is the process of preparing water for reuse in toilet flushing and landscape irrigation. This stage occurs in the treatment pond (Figure 3). The treatment pond has drainage pipes under the boundary layer of the pond which allow the discharge of treated water into the water tank as well as its further reuse. Adding calcium, aluminum, and iron-containing compounds to the filtration layer provides addition elimination of phosphorus. The total elimination of pathogenic bacteria also occurs in the fourth stage, resulting in treated water that meets the requirements for bathing water and the level of organic compounds contamination is similar to slightly polluted surface water. 


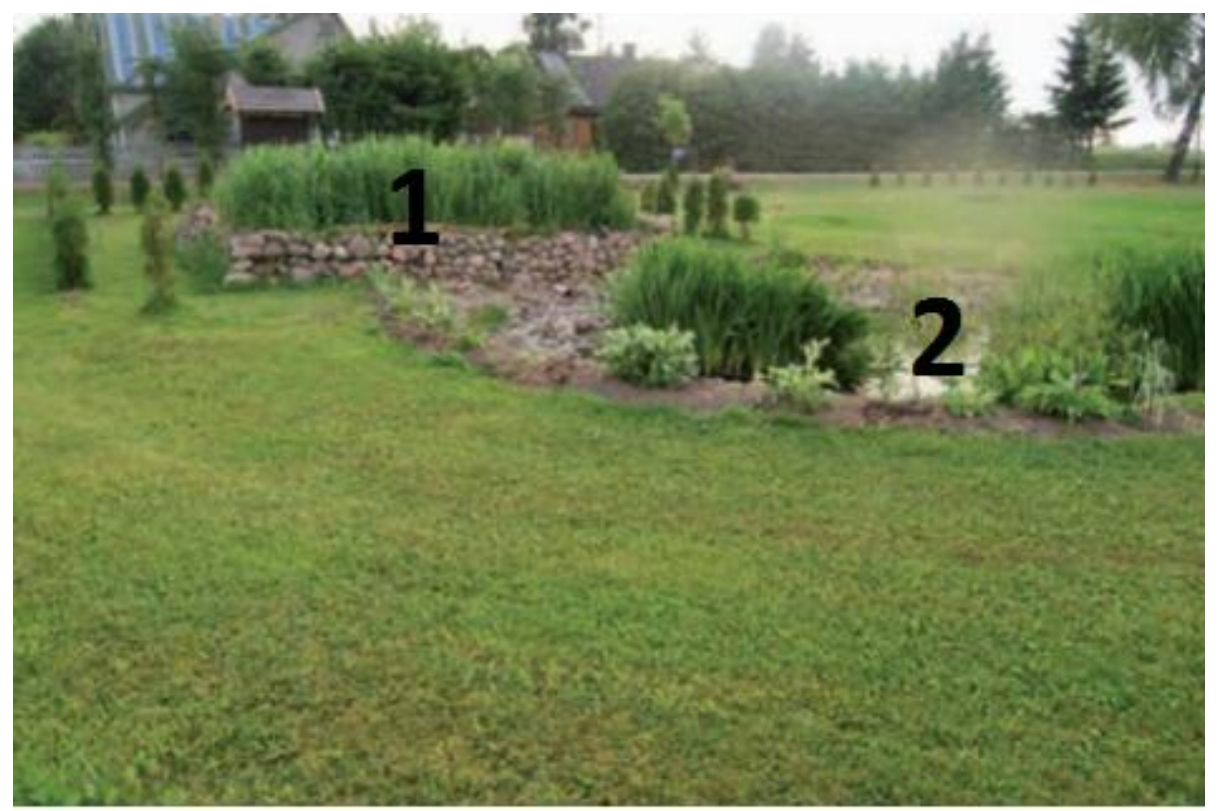

Figure 4. An existing Improved Wetland System for maximum 20 persons

Note: 1 plants filter, 2 treatment pond

\section{Elimination of Organic Compounds in Improved Wetland Systems}

Reduction of organic compounds in domestic and local wastewater treatment plants could constitute in average 50\% just after pre-treatment in a septic tank. In the pre-treatment step the rapidly degradable compounds are reduced through sedimentation and as a result of anaerobic processes in the septic tank. The remainder of the organic compounds are degraded in aerobic processes to about $90 \%$. Therefore, the most important objective is creating favorable conditions for aerobic bacteria. Wastewater treatment using bacteria occurs in all technologies such as trickling filter, activated sludge and wetland systems. Improved wetland systems for wastewater treatment process use not only bacteria, but also fungi, protozoa, mites, nematodes, earthworms, enchytraeldae as well as marsh plants and algae. The use of multiple organisms to eliminate organic compounds is made possible by the special structure and functions of the filter and treatment pond (described in paragraph 4). An essential element that provides the reduction of organic compounds is the filter. Years of IWS research has shown the existence of a direct correlation between loading filter and concentration of $\mathrm{BOD}_{5}$ and COD in outflow from filter, as shown in Figure 5 and 6. 
Filter loading $\left[\mathrm{g} \mathrm{BOD}_{5} / \mathrm{m}^{2} / \mathrm{d}\right]$

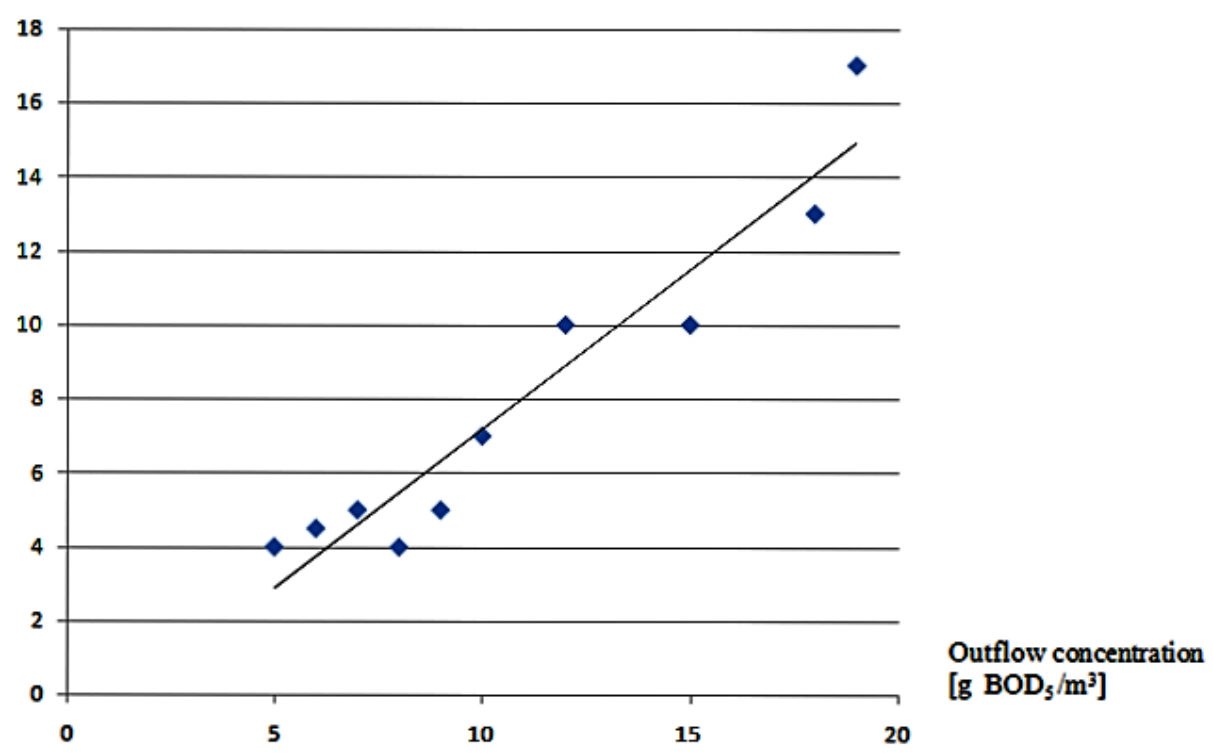

Figure 5. The relationship between filter loading and concentration of $\mathrm{BOD}_{5}$ in outflow of filter in IWS

Filter loading [g COD $/ \mathrm{m}^{2} / \mathrm{d}$ ]

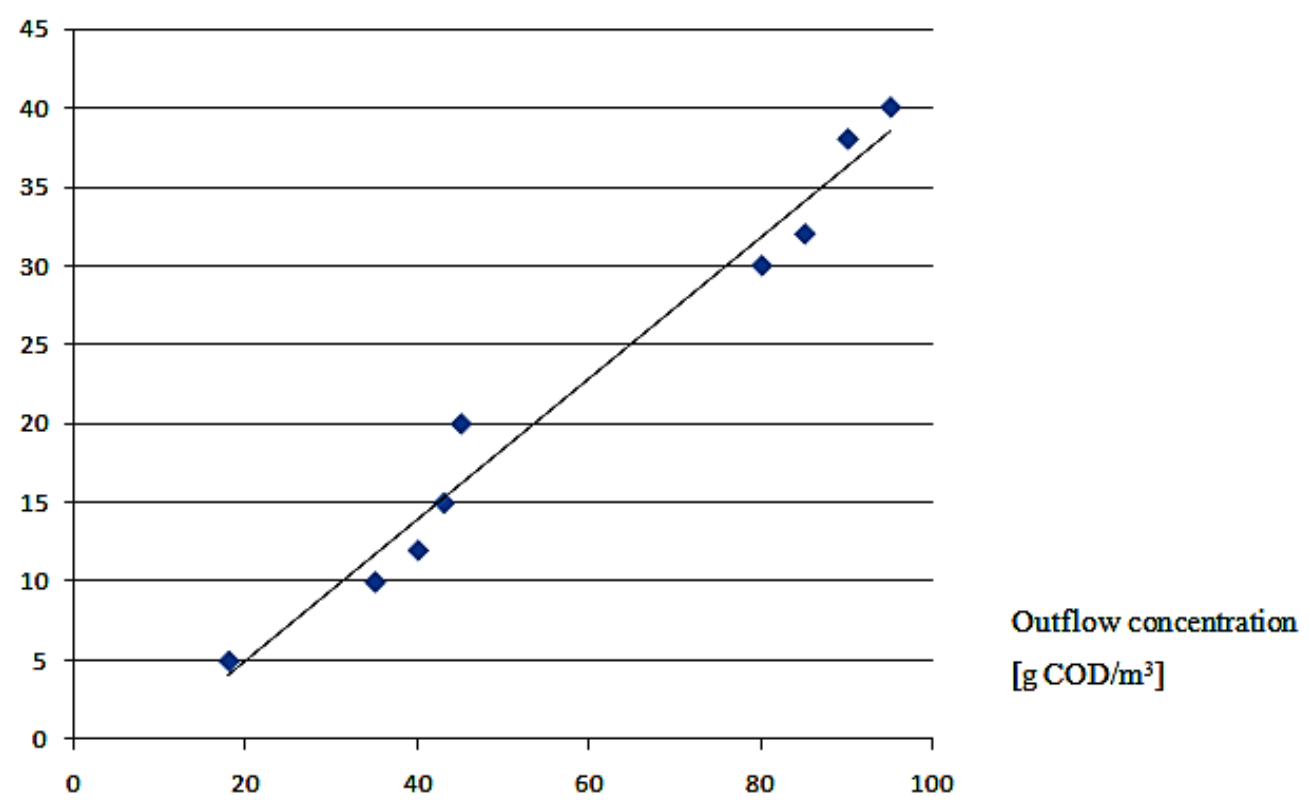

Figure 6. The relationship between filter loading and concentration of COD in outflow of filter in IWS 
Figures 5 and 6 apply to the filter described in paragraph 4 and are available in a range of hydraulic loads from 0.05 to $0.1 \mathrm{~m}^{3} / \mathrm{m}^{2} / \mathrm{d}$. In addition, figure 5 and 6 show average-year values, which can be changed for several reasons:

- Reduction of active surface area. Due to incorrect wastewater distribution on the filter, wastewater is unevenly separated. The result is an increased contaminant $\left(\mathrm{BOD}_{5}, \mathrm{COD}\right)$ and hydraulic load of filter surface.

- Lack of proper cover plants. The result is a change in the treatment conditions in the filter. Places without plants quickly lose hydraulic conductivity and treatment efficiency decreases.

The relationship between filter loading of $\mathrm{BOD}_{5}$ and $\mathrm{COD}$ and its concentrations in outflow from filter causes that the concentrations in the outflow can be planned and intentional. In the case of the planned reuse of water it is recommended to designate about $10 \mathrm{~g}$ of contaminant load per square meter for one day - $\mathrm{BOD}_{5}$ and about $20 \mathrm{~g} / \mathrm{m}^{2} / \mathrm{d}-\mathrm{COD}$. Then, the average concentration of organic compounds in the outflow from the plant filter is made up of about $5 \mathrm{~g} \mathrm{BOD}_{5} / \mathrm{m}^{3}$ and $40 \mathrm{~g} \mathrm{COD} / \mathrm{m}^{3}$. According to paragraph 2 the $\mathrm{BOD}_{5}$ concentration in the outflow from plants filter which constitute $5 \mathrm{~g} / \mathrm{m}^{3}$ classifies water to slightly polluted. The further treatment of this water in order to reduce the further content of organic compounds is difficult. The reason is the unfavorable ratio of $\mathrm{COD}$ to $\mathrm{BOD}_{5}$ in outflow from the filters plants which constitute $8: 1\left(40 \mathrm{~g} / \mathrm{m}^{3}\right.$ COD: $\left.5 \mathrm{~g} / \mathrm{m}^{3} \mathrm{BOD}_{5}\right)$. Table 2 shows the effect of the ratio $\mathrm{COD}$ to $\mathrm{BOD}_{5}$ for biochemical decomposition of organic compounds. Comparing the ratio which occurs in the outflow from the filter to the data in Table 2, it shows that further degradation of the remaining organic compounds is very limited. According to Table 2 a ratio greater than 10 prevents further degradation. Therefore, use of the second stage such as a treatment pond is necessary to achieve lower concentration of $\mathrm{BOD}_{5}$ and $\mathrm{COD}$ in outflow.

Table 2. The susceptibility of organic compounds decomposition depending on the ratio of $\mathrm{BOD}_{5}$ to COD (Sontheimer, 1986)

\begin{tabular}{|c|c|}
\hline Ratio of $\mathrm{BOD}_{5}$ to COD & The susceptibility of organic compound to decomposition \\
\hline$<1,7$ & Very high, possibly full biochemical decomposition \\
\hline $1,7-10$ & Lower, partial biochemical decomposition, \\
\hline$>10$ & Inability to carry out biochemical decomposition \\
\hline
\end{tabular}

In the treatment pond there is further decomposition of organic compounds. The first stage of treatment in treatment pond is phytoplankton bloom in water which results in a several fold increase primarily of $\mathrm{BOD}_{5}$ and in to a low extent $\mathrm{COD}$. As a result, the ratio of COD to $\mathrm{BOD}_{5}$ decreases from $8-10$ to the range $2-5$. The intense phytoplankton bloom in the pond is caused by nitrogen and phosphorus contained in water. The phytoplankton bloom occurs from spring to autumn but in the winter when the surface of the pond is frozen the process is completely inhibited. In the second stage of treatment in treatment pond, water containing algae soaks through the filter layer. During this time in filter layer occurs algae filtration from water and biochemical decomposition of dissolved organic compounds. The result of these 
processes is the reduction of $\mathrm{BOD}_{5}$ concentration to a value less than $1 \mathrm{~g} / \mathrm{m}^{3}$. In the case of the COD the effect is lower because the reduction in the concentration reaches a maximum of $50 \%$. It depends on various factors such as:

- Retention time in pond; if the time is more than 10 days the level of reduction is higher,

- Thickness of the filter layer; if it is more than $30 \mathrm{~cm}$ the reduction of the concentration of $\mathrm{COD}$ and $\mathrm{BOD}_{5}$ may increase,

- Soil texture; if the fraction of silt and clay is greater, the efficiency of the reduction of the concentration increases,

- The thickness of organic deposits on the surface of the filtration layer.

The treatment pond, despite many of its technology functions, is also a decorative object and its surface should be the largest. In order to reduce the $\mathrm{BOD}_{5}$ to a value less than $1 \mathrm{~g} / \mathrm{m}^{3}$ and value of COD less than $30 \mathrm{~g} / \mathrm{m}^{3}$ surface of the pond should be $3 \mathrm{~m}^{2}$ per person. However, due to the above-mentioned additional functions it is recommended that the surface should be $5 \mathrm{~m}^{2}$ per person.

\section{Conclusion}

The use of improved wetland systems for wastewater treatment from individual homes or small settlements allows obtaining water quality similar to natural waters or slightly contaminated waters in terms of organic compounds. Treated wastewater can be used for reuse in toilet flushing and landscape irrigation. The first such systems have been operating in Poland for many years. Their operation has shown that under local conditions the reuse of treated wastewater can bring not only environmental benefits such as decreasing the consumption of tap water but also economic advantages. The cost of materials is on average 1500 euro, while construction costs range from 1000 to 1500 euro. Additionally, energy consumption and operating costs are lower than those of conventional wastewater treatment systems. In Poland operating costs are 20 euros per year and include emptying a septic tank once every 3 years, energy costs, and the costs of cutting plants.

From a technical point of view the use of improved wetland systems is not complicated. To obtain the outflow of water with a composition similar to natural uncontaminated surface water the system needs the following:

- $\quad$ pretreatment of wastewater in the septic tank 2 or 3 chamber, where the wastewater will be staying for at least 5 days,

- filter operating at an average filter loading of $\mathrm{BOD}_{5}$ about $10 \mathrm{~g} / \mathrm{m}^{2} / \mathrm{d}$ and the hydraulic load about 0.05 to $0.1 \mathrm{~m}^{3} / \mathrm{m}^{2} / \mathrm{d}$,

- treatment pond with an area of $5 \mathrm{~m}^{2}$ per one person,

According to the Polish experience, such systems may operate for many years, also in winter when the ambient temperature decreases below - 20 degrees. Use of IWS for wastewater 
treatment and reuse took different forms in Poland. For many years Improved Wetland System treatment of wastewater have served as recreation areas, supplied reservoirs and created a living environment for endangered animal species (Halicki, 2016). The versatility of IWS is caused by high treatment efficiency in domestic, local and large wastewater treatment systems.

\section{References}

Allen, L., Chistian-Smith, J., \& Palaniappan, M., (2010). Overview Of Graywater Reuse : The Potential Of Greywater Systems To Aid Sustainable Water Management, Pacific Institute.

Babcock, W., Asce, M., Daniel, A. M., Lance, A. E., \& Harold, N. (2004). Evaluation of a System for Residential Treatment and Reuse of Wastewater, Journal of Environmental Engineering, 130(7). https://doi.org/10.1061/(ASCE)0733-9372(2004)130:7(766)

Chapmon, D., (1996). Water Quality Assessments.(2nd ed.). A Guide to use of biota, sediments and water in enviromentalmonitoring, London.

https://doi.org/10.4324/noe0419216001

Cho, Y., \& Roesner, L. (2007). Treatment Effect of Graywater through a Tandem Wetland. World Environmental and Water Resources Congress, 1-9.

https://doi.org/10.1061/40927(243)567

Crook, J. (1998). Water Reclamation and Reuse Criteria. In R. Surampalli, \& K. Tyagi, Advances in Water and Wastewater Treatment, American Society of Civil Engineers. 303-329.

Halicki, W. (2015) Ekologia stosowana w żrównowazonej gospodarce wodno-ściekowej. Wydawnictwo Instytutuwe ISBN: 978-83-922273-4-2, Skórzyn.

Halicki, W., Zajac, A., \& Kita, K., (2016). Posibilities of developing municipal sewage treatment technologies using constructed wetlands and tritment ponds. In 15 th IWA International Conference on Wetland Systems for Water Pollution Control. Gdansk Poland, ISBN 83-60261-14-8.

Imhoff, K., \& Imfoff, K. R., (1993). Taschenbuch der Stadtentwasserung, Munchen-Wien: R. Oldenbourg Verlag

Jokerst, A., Roesner, L., \& Sharvelle, S. (2009) An Evaluation of Graywater Reuse Utilizing a Constructed Wetland Treatment System. World Environmental and Water Resources Congress, 1-10. https://doi.org/10.1061/41036(342)561

Nasiri, F., Savage, T., Wang, R., Barawid, N., \& Zimmerman, J. (2013). A system dynamics approach for urban water reuse planning: a case study from the Great Lakes region. Stochastic Environmental Research and Risk Assessment, 675-691. https://doi.org/10.1007/s00477-012-0631-8

Powszechny Spis Rolny (2010), Raport, Główny Urząd Statystyczny, Warszawa, Olsztyn, 


\section{Macrothink}

Rozporządzenie Ministra Środowiska z dnia 22 października 2014 r. w sprawie sposobu klasyfikacji stanu jednolitych części wód powierzchniowych oraz środowiskowych norm jakości dla substancji priorytetowych; (Dz. U. z dnia 30 października 2014 r.)

Sontheimer, H., Spindler, P., \& Rohmann, U. (1986): Wasserchemie fur Ingenieure. DVGW Forchungstelle am Engler-Bunte-Institut der Universitet Karlsruhe.

Statistical Office (2014). Municipal Infrastructure, Warsaw, 2015;

Statistical Office of the European Union ( 2015)

United Nations Development Program (2006). Human Development Report

Vassos, T. (2014). Water Reclamation \& Reuse: Understanding the promise and the potential. Municipal World, 27-30.

\section{Copyright Disclaimer}

Copyright for this article is retained by the author(s), with first publication rights granted to the journal.

This is an open-access article distributed under the terms and conditions of the Creative Commons Attribution license (http://creativecommons.org/licenses/by/3.0/). 